\section{Communicative Language Teaching in Indonesia: Issues of Theoretical Assumptions and Challenges in the Classroom Practice}

\author{
Bachrudin Musthafa \\ Universitas Pendidikan Indonesia, Bandung
}

\begin{abstract}
Trying to keep abreast to recent development in ESL pedagogy, Indonesian Government-in this case Ministry of National Education-has for the past two decades been trying to reform English instruction at the junior and senior high schools across the country. This article describes the issues surrounding the reform initiative and the response the system has made to address the issues. The existing, problematic conditions are delineated and possible ways for improvement are then put forth.
\end{abstract}

Key words: CLT, Communicative Approach; reform in English teaching; instructional problems in English education

Like other reform efforts in the world, the emergence of "Communicative Language Teaching" in public discourse and, later on, its institution of the "Communicative English Teaching Approach" in Indonesia's schools represents a response to our disappointments with the theories coming before it. Even the term "Communicative Approach" itself, in the context of English Curriculum for SLTP (Middle School) and SMU (Senior High School), has taken different social meanings. First, in the 1984 English Syllabus, the communicative approach was "misinterpreted" as oral-based language instruction and its implementation aroused controversies. The same approach has now been redefined and given a new name: "Meaningful Approach" (Huda, 1999).

For classroom teachers-despite the changing names-the primary concerns remain unchanged. That is, where are we supposed to go with the English Language Teaching? How can we help students to learn English most effectively and efficiently so that, upon completion of the course, they can use the language for real-life purposes? What supports has the curriculum made available to teachers so that the stated goals become achievable? What else should we do with our own resources to make our student learning optimal?

This paper shall address these issues and elaborate on the implications each of the issues might bring to the fore by, first, detailing the language acquisition principles underlying the 1994 English Curriculum. The discussion, then, moves on to spell out the enabling condition that should be present or created so that the stated goals (become) achievable. To siluate the discussion into a more realistic context, some observations on the reality of the classroom in particular, and schools in general, will be outlined.

Next, drawing on the discussion on the instructional principles, support requirements and contextual constraints, the paper presents some common challenges that classroom teachers are confronted with. To conclude the discussion, some strategies to overcome contextual constraints are then discussed and some practical suggestions put forth to inspire classroom teachers to improve instruction by way of integration of linguistic macro-skills.

\section{THE 1994 ENGLISH CURRICULUM: PRINCIPLES AND REQUTREMENTS} FOR SUCCESSFUL IMPLEMENTATION

The 1994 English Curriculum, which is currently in effect, represents an outgrowth of its predecessor, the 1984 English Curriculum. Both curricula, actually, share the same theoretical underpinnings. That is, both have drawn very heavily from studies in language acquisition originated in the USA, language instruction program that emphasizes total language exposure (e.g., Language Experience Approach, Total Immersion Program, etc.), and the European course credit system (cf. Stern, 1983). As an amalgam of a wide array of different theories and instructional programs, the implementation of communicative language teaching principles can take many different forms. Upon closer analyses, however, some characteristics are clearly shared by the communicative approach to language teaching. These characteristics, which represent the major objectives of the approach, include what are explicitly spelled out in the 1994 curriculum guide as the following:

- Development of communicative competence-the ability to use En- 
glish for communicative purposes-which covers all four macroskills: reading, listening, speaking, and writing; efforts should be made to strike a good balance among the four macro-skills;

- Mastery of linguistic aspects are to be used to support communicative abilities in both oral and written forms;

- The English syllabus represents an amalgam of various forms of syllabi: functional, situational, skills-based, and structural; given the nature of the syllabus, the basis for the organization of the materials is not linguistic aspects but topical themes and functional skills; -

- Assessment is integrated (covering more than one language components) and communicative (not exclusively on linguistic elements)

- Not all instructional objectives are measurable using a paper-andpencil test (e.g., reading for enjoyment)

To better understand how these principles can be translated into classroom instructional activities, a closer look at some key words and/or phrases are in order: "communicative competence", "topical themes", "functional skills", "integrated assessment", "communicative assessment", and "reading for enjoyment".

\section{Communicative Competence: What it is and how it develops}

Many experts have defined the term communicative competence, and they generally agree that it means the ability to use a language for communicative purposes. Canale and Swain (1979) have further specified the components of communicative competence in four areas:

1. Grammatical competence, the ability to apply the rules of grammar to produce or interpret ideas to gather a message correctly. Known very well to teachers who were trained in the heyday of structuralism afd/or audiolingualism, grammatical competence used to be the only focus of English instruction in the past. This linguistic competence is, indeed, important because without it learners of English will not be able to use the language correctly. Without well-developed grammatical competence, that is to say, learners of English are unable to function in the language in a sophisticated way as they can only use English at the level of vocabulary words. Research in language acquisition and verbal communication has established that grammar, when taught in isolation from its contextualized communicative use, tends to be acquired by learners as merely linguistic property. It is evidenced in many studies which show that grammatical knowledge does not automatically transfer to actual communicative acts such as writing and reading for real-life purposes (e.g., writing letters to a friend; to the Editor of Newspapers/Magazines; reading to acquire new knowledge; to accomplish a task; reading to experience literary works, etc.) Grammatical knowledge is, indeed, useful to learners of English to the extent that it enables them to use the language for such communicative purposes.

2. Discourse competence, the ability to connect several ideas together appropriately and to maintain an extended exchange of messages. For this competence to develop properly, learners of English need to get exposed to- and engaged in - extended discourses in the context of communicative events (e.g., taking notes from lectures in English; participating in discussions/debates, etc.)

3. Sociolinguistic competence, the ability to choose language usage according to the social situations (including such aspects as time, place, and social relationships). Like other aspects of communicative competence, sociolinguistic competence assumes the communicative use of the language. As the competence is embedded in social interactions, for learners to develop their sociolinguistic competence it is necessary that they get exposed to and engaged in various uses of English in a wide array of social situations and role relationships.

4. Strategic competence, the ability to understand a basic meaning or to be understood, even when adequate vocabulary and structures are lacking. It manifests itself mostly in strategies used by communicators (e.g., speakers, writers) to avoid communication breakdown, especially when words cannot sustain the communication flow. Given its very nature, again, this competence assumes communication activities for its development.

To help learners of English develop into competent users of English, therefore, the English language instruction must base itself on the current understanding of the nature of the communicative competence and how, according to research, it develops. To better situate our discussion, it is useful to describe what it means to be communicatively competent.

In our context of English language teaching in SLTP and SMU, communicatively competent students can be described as follows.

- When speaking, the students are able to find what is appropriate to say, how it should be said, and when, in different social situations in 
which they find themselves. This understanding brings with it a serious implication for curriculum development-for instance, basing the curricular items on the best knowledge we have about what the target group of learners need and what preferences are. Or, better still, the curriculum can be negotiated and jointly constructed with the target learners to ensure sense of relevance, ownership, and authentic processing on the part of the learners.

- When listening, the students can use all contextual clues to get the meaning of what is being said and how the message is being conveyed.

- When reading, the students are able to construct the meaning based on the messages provided by the text and in transaction with their own reading purposes.

- When writing, the students are able to formulate their ideas into acceptable written English language in accordance with the writing situation and their own writing purposes.

Theme-based English instruction: What it is, and how it can contribute to the development of communicative competence

Communicative activities always occur in a social context; and the social context always implies two or more interlocutors (or participants) involved in a communicative event, which is embedded in a certain time and place. "Themes" here are believed to be a practical way to preserve both linguistic and social dimensions of communicative events. In other words, organizing English instruction around themes would enable curriculum designers, materials developers, and instructors to present learning materials in a way that has relatively strong flavor of authentic communication. In this way, it is hoped, that students are not only exposed to linguistic expressions but also to settings (time, place, and role relationships) where the expressions are naturally used for some communicative purposes. This is especially important to promote the development of sociolinguistic competence.

\section{Functional Skills: What they are and how they develop}

Learning from previous experiences where language instructional materials were presented in grammatical terms - which have resulted in much resentment among language educators and teachers alike-in the context of theme-based instruction, linguistic skills can be presented in the context of purpose-driven social exchanges. With the features of communicative events preserved in the themes, the communicative skills involved in the exchanges appear more functional. The functionality of these skills is important for learners to keep their motivation high because, in this way, they can see for themselves that what they learn has some utilitarian value.

\section{Integrated/Communicative Assessment}

Communicative language teaching makes use of real-life situations that necessitates communication (Galloway, 1993). And a normal communication event generally requires the use of many linguistic skills-not only one skill at a time, like what is usuaily assessed in the grammarbased curriculum. For instance, when we are engaged in conversational exchanges, both listening and speaking are called into use; in some context it can happen that a communicative event requires us to use all the four macro linguistic skills in a single event (e.g. formal debates or lectures).

Given the nature of communicative acts, the assessment should cover more than one skill at the same time and, better still, it should be embedded in real-life communicative activities.

\section{Reading for Enjoyment}

One very important purpose of communicative language teaching is to enable learners to use the language for real-life communicative purposes. As part of being a member of literate culture, our students are expected to read on their own for the purposes they set for themselves. For example, they might want to read comics, short stories or novels to entertain themselves. Or, they might want to update their knowledge about things they consider important.

Voluntary reading such as this one is important for the students' personal development both as a language learner as well as a member of a literate society.

\section{ENABLING CONDITIONS FOR COMMUNICATIVE SKILLS DEVELOPMENT}

Research evidence abounds which suggests that certain conditions are required to enable language learners to develop into communicativelycompetent participants in social interactions in the English language. One obvious example is that students need to have good models to learn 
from - and a great amount of exposure to - the language use in the reallife context. They also need opportunities to acquire these models and get involved in meaningful communicative events. For their optimal development as an active participant in meaningful social interactions and/or social dialogs, the language learners need to have a supportive environment surrounding them

In other words, only when we can provide this enabling condition can we reasonably expect that our students get developed into communicatively competent users of English.

\section{REALITY OF THE LANGUAGE CLASSES IN INDONESIAN SCHOOLS}

As many Indonesian secondary and high school teachers of English can attest, such an enabling condition is not always easy to create in our schools. Many reasons can explain why this is so. One is teachers' degree of confidence in using the language before their own students. In a situation where a teacher fails to show confidence and enthusiasm in what s/he teaches it is difficult to encourage students to become otherwise. A second reason might be the time constraint, which practically precludes the teachers to design an instructional session that requires learners to get involved in social communication in the classroom. Commonly packed with about thirty to forty students in one classroom, and coupled with a crowded curriculum, many teachers cannot afford to provide well-designed, meaningful exercises for students to use what is being learned on one-to-one basis. Another reason could be the type and focus of the exam, based on which students' relative success in learning English is judged. As it is presently practiced, the nationally-administered test (i.e., EBTANAS) is commonly dominated by questions which are form-focused and presented in a multiple-choice format, which does not allow divergent thinking. This kind of test can be counterproductive because it sends a wrong message to students. In this case, it is very likely that the learners of English misconstrue the test as an encouragement to think that good grammar is the only thing to take care of if they want to develop themselves into communicatively competent individuals.

Other hindrances can be listed here: the absence of good, authentic learning materials, teachers' tendency to rely on non-communicativelyengaging learning tasks (such as those grammar-based worksheets), and the absence of visible social uses of the language outside the classroom confine.
All of this can stand in the way to the development of sense of relevance in learning English, which can, in turn, create further psychological distance on the part of the learners.

\section{CHALLENGES IN CLASSROOM PRACTICE}

Given the reality that we have, to reiterate, the most serious challenge facing our English teachers is the absence of-or insufficient amount of - exposure to real-life English use, student engagement in real-life communicative activities and all kinds of environmental supports whichaccording to research-are contributive to the development of learners as a communicatively-competent user of the English language. These important-but non-existent - supports include communicatively-oriented exit exams, realistic behavioral models of how English is used to satisfy the needs for real-life communication and social interactions, and communication-based instructional materials.

As indicated earlier, the tests given to the students-which are run nationally - focus on knowledge of syntax and grammatical items, although many teachers and curriculum developers have realized that this practice is counterproductive to the attempt to develop students' communicative competence. This nationally mandated policy seems to be adopted because some decision-makers wrongly believe that communicativelyoriented testing instruments are difficult and expensive to develop. The absence of communicatively-designed testing instruments coupled with the fact that the English language is not used in our day-to-day social communication has made communication-based instructional materials lose their pedagogical values.

Consistent with this observation, many Indonesian teachers of English have publicly admitted in seminars - and this has also been supported by my personal observation in many different contexts - that English is seldom used in the classroom as the teachers tend to use Bahasa Indonesia to carry out their English lessons in the classroom-except, perhaps, when greeting students before the sessions get started and, then, when they get dismissed. In a situation such as this one, students are practically not given any good, functional English language uses to model from. It is, then, difficult to imagine how students in this learning environment would develop a good sense of purpose and direction in learning the language. 


\section{SUGGESTED STRATEGIES TO PROMOTE MEANINGFUL LANGUAGE LEARNING}

Some experts have argued that a language activity is meaningful when learners see in what they are doing clear and reasonably good reasons why they do what they do (see, for instance, Smith, 1988). To ensure "meaningfulness" then, we teachers should, at the very least, make explicit the objectives we want our students to achieve as a result of their engagement in learning activities that we have devised. The clarity of the objective is also important to enable students to assess their relative success in learning from literacy activities they engage in.

Learning a language would also be greatly enhanced when the learners see in what they learn some sense of personal relevance. It-is therefore important for teachers (and materials developers alike) to base the learning materials on some things dear to the learners because, according to Frank Smith as cited in Musthafa 1994, only when they consider the materials relevant will the students commit their optimal attention to learning.

\section{REFERENCES}

Brumfit, C. 1989. Communicative Methodology in Language Teaching: The Roles of Fluency and Accuracy. New York, NY: Cambridge University Press. Candlin, C.N. 1980. The Communicative Teaching of English: Principles and $\bar{A}$ Exercise Typology. Essex, England: Longman Group Limited.

Huda, N. 1999. Language Learning and Teaching: Issues and Trends. Malang: IKIP Malang Publisher

Littlewood, W. 1981. Communicative Language Teaching. New York, NY: Cambridge University Press.

Müsthafa, B. 1994. Literary Response: A Way of Integrating Reading-Writing Activities. Reading Improvement, Vol.31, No.1, pp.52-58.

Musthafa, B. 1996. Learning from Texts and Reading Instruction. ERIC Reports (ED395268). Washington, DC: U.S. Department of Education, Office of Educational Research and Improvement (OERI)

Musthafa, B. 1997. Content Area Reading: Principles and Strategies to Promote Independent Learning. TEFLIN Journal, Vol.III, No.1, pp.37-49.

Palmer, AS, Groot, PJ, and Trosper, GA (Eds.). 1981. The Construct Validation of Tests of Communicative Competence. Washington, DC: TESOL
Richards, J. C. 1990. The Language Teaching Matrix. New York, NY: Cambridge University Press.

Smith, F. 1988. Understanding Reading: A Psycholinguistic Analysis of Reading and Learning to Read. Hillsdale, New Jersey: LEA Publishers. 